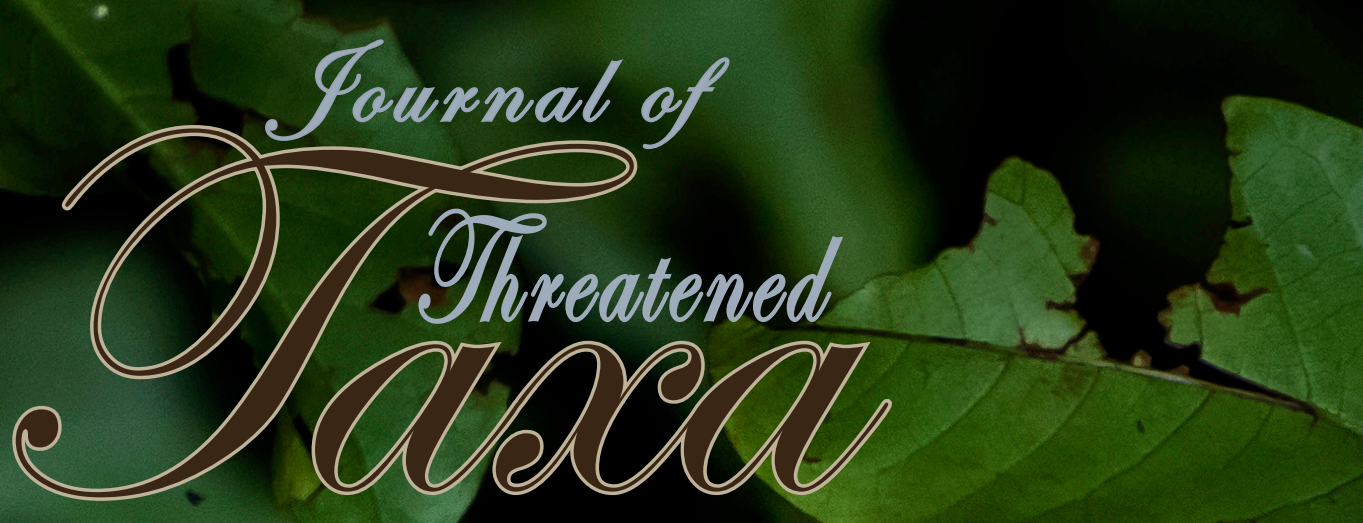

Building exidence for conservation glabally

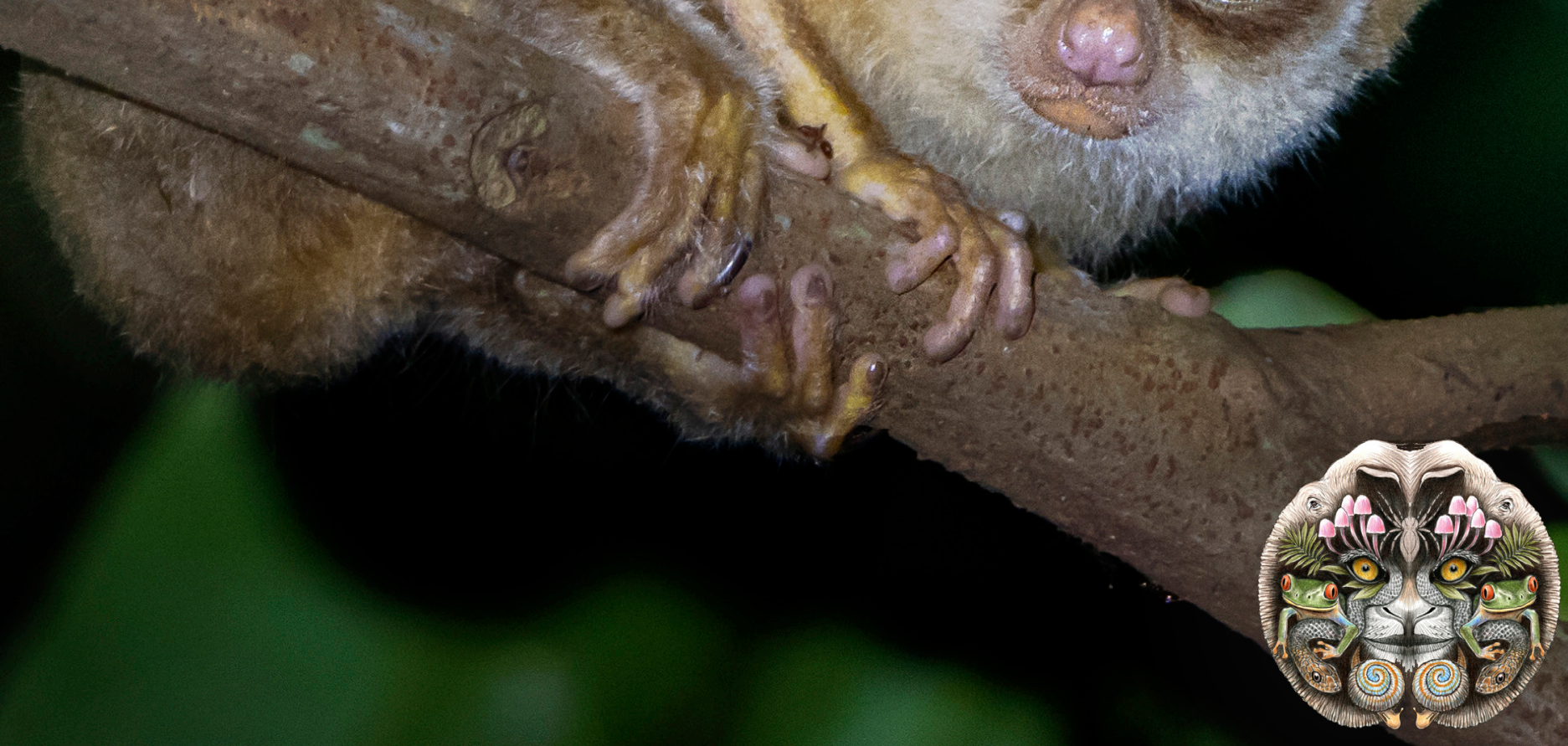

Open Access

$10.11609 /$ jott.2021.13.010.19431-19614 creven.threatenedtaxa.arg

26 September 2021 (Online \& Print) Val. 13 | Na. 11 | Pages: 19431-19674 


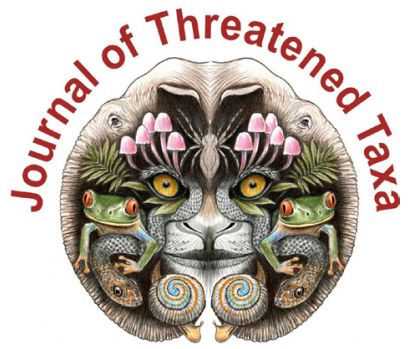

ISSN 0974-7907 (Online); ISSN $0974-7893$ (Print)

Publisher

Host

Wildlife Information Liaison Development Society

www.wild.zooreach.org

Zoo Outreach Organization www.zooreach.org

No. 12, Thiruvannamalai Nagar, Saravanampatti - Kalapatti Road, Saravanampatti, Coimbatore, Tamil Nadu 641035, India

Ph: +91 9385339863 | www.threatenedtaxa.org

Email: sanjay@threatenedtaxa.org

EDITORS

\section{Founder \& Chief Editor}

Dr. Sanjay Molur

Wildlife Information Liaison Development (WILD) Society \& Zoo Outreach Organization (ZOO)

12 Thiruvannamalai Nagar, Saravanampatti, Coimbatore, Tamil Nadu 641035, India

\section{Deputy Chief Edito}

Dr. Neelesh Dahanukar

Noida, Uttar Pradesh, India

\section{Managing Editor}

Mr. B. Ravichandran, WILD/ZOO, Coimbatore, India

\section{Associate Editors}

Dr. Mandar Paingankar, Government Science College Gadchiroli, Maharashtra 442605, India

Dr. Ulrike Streicher, Wildlife Veterinarian, Eugene, Oregon, USA

Ms. Priyanka Iyer, ZOO/WILD, Coimbatore, Tamil Nadu 641035, India

Dr. B. A. Daniel, $200 / \mathrm{WILD}$, Coimbatore, Tamil Nadu 641035, India

\section{Editorial Board}

Dr. Russel Mittermeier

Executive Vice Chair, Conservation International, Arlington, Virginia 22202, USA

\section{Prof. Mewa Singh Ph.D., FASc, FNA, FNASc, FNAPsy}

Ramanna Fellow and Life-Long Distinguished Professor, Biopsychology Laboratory, and Institute of Excellence, University of Mysore, Mysuru, Karnataka 570006, India; Honorary Professor, Jawaharlal Nehru Centre for Advanced Scientific Research, Bangalore; and Adjunct Professor, National Institute of Advanced Studies, Bangalore

\section{Stephen D. Nash}

Scientific Illustrator, Conservation International, Dept. of Anatomical Sciences, Health Sciences Center, T-8, Room 045, Stony Brook University, Stony Brook, NY 11794-8081, USA

\section{Dr. Fred Pluthero}

Toronto, Canada

\section{Dr. Priya Davidar}

Sigur Nature Trust, Chadapatti, Mavinhalla PO, Nilgiris, Tamil Nadu 643223, India

\section{Dr. Martin Fisher}

Senior Associate Professor, Battcock Centre for Experimental Astrophysics, Cavendish

Laboratory, JJ Thomson Avenue, Cambridge CB3 OHE, UK

\section{Dr. John Fellowe}

Honorary Assistant Professor, The Kadoorie Institute, 8/F, T.T. Tsui Building, The University of Hong Kong, Pokfulam Road, Hong Kong

\section{Prof. Dr. Mirco Solé}

Universidade Estadual de Santa Cruz, Departamento de Ciências Biológicas, Vice-coordenado do Programa de Pós-Graduação em Zoologia, Rodovia Ilhéus/Itabuna, Km 16 (45662-000)

Salobrinho, Ilhéus - Bahia - Brasil

\section{Dr. Rajeev Raghavan}

Professor of Taxonomy, Kerala University of Fisheries \& Ocean Studies, Kochi, Kerala, India

\section{English Editors}

Mrs. Mira Bhojwani, Pune, India

Dr. Fred Pluthero, Toronto, Canad

Mr. P. Ilangovan, Chennai, India

Web Maintenance

Mrs. Latha G. Ravikumar, ZOO/WILD, Coimbatore, India

\section{Typesetting}

Mr. Arul Jagadish, ZOO, Coimbatore, India

Mrs. Radhika, ZOO, Coimbatore, India

Mrs. Geetha, ZOO, Coimbatore India

\section{Fundraising/Communications}

Mrs. Payal B. Molur, Coimbatore, India

Subject Editors 2018-2020

Fungi

Dr. B. Shivaraju, Bengaluru, Karnataka, India

Dr. R.K. Verma, Tropical Forest Research Institute, Jabalpur, India

Dr. Vatsavaya S. Raju, Kakatiay University, Warangal, Andhra Pradesh, India

Dr. M. Krishnappa, Jnana Sahyadri, Kuvempu University, Shimoga, Karnataka, India

Dr. K.R. Sridhar, Mangalore University, Mangalagangotri, Mangalore, Karnataka, India

Dr. Gunjan Biswas, Vidyasagar University, Midnapore, West Bengal, India

Plants

Dr. G.P. Sinha, Botanical Survey of India, Allahabad, India

Dr. N.P. Balakrishnan, Ret. Joint Director, BSI, Coimbatore, India

Dr. Shonil Bhagwat, Open University and University of Oxford, UK

Prof. D.J. Bhat, Retd. Professor, Goa University, Goa, India

Dr. Ferdinando Boero, Università del Salento, Lecce, Italy

Dr. Dale R. Calder, Royal Ontaro Museum, Toronto, Ontario, Canada

Dr. Cleofas Cervancia, Univ. of Philippines Los Baños College Laguna, Philippines

Dr. F.B. Vincent Florens, University of Mauritius, Mauritius

Dr. Merlin Franco, Curtin University, Malaysia

Dr. V. Irudayaraj, St. Xavier's College, Palayamkottai, Tamil Nadu, India

Dr. B.S. Kholia, Botanical Survey of India, Gangtok, Sikkim, India

Dr. Pankaj Kumar, Kadoorie Farm and Botanic Garden Corporation, Hong Kong S.A.R., China

Dr. V. Sampath Kumar, Botanical Survey of India, Howrah, West Bengal, India

Dr. A.J. Solomon Raju, Andhra University, Visakhapatnam, India

Dr. Vijayasankar Raman, University of Mississippi, USA

Dr. B. Ravi Prasad Rao, Sri Krishnadevaraya University, Anantpur, India

Dr. K. Ravikumar, FRLHT, Bengaluru, Karnataka, India

Dr. Aparna Watve, Pune, Maharashtra, India

Dr. Qiang Liu, Xishuangbanna Tropical Botanical Garden, Yunnan, China

Dr. Noor Azhar Mohamed Shazili, Universiti Malaysia Terengganu, Kuala Terengganu, Malaysia Dr. M.K. Vasudeva Rao, Shiv Ranjani Housing Society, Pune, Maharashtra, India

Prof. A.J. Solomon Raju, Andhra University, Visakhapatnam, India

Dr. Mandar Datar, Agharkar Research Institute, Pune, Maharashtra, India

Dr. M.K. Janarthanam, Goa University, Goa, India

Dr. K. Karthigeyan, Botanical Survey of India, India

Dr. Errol Vela, University of Montpellier, Montpellier, France

Dr. P. Lakshminarasimhan, Botanical Survey of India, Howrah, India

Dr. Larry R. Noblick, Montgomery Botanical Center, Miami, USA

Dr. K. Haridasan, Pallavur, Palakkad District, Kerala, India

Dr. Analinda Manila-Fajard, University of the Philippines Los Banos, Laguna, Philippines

Dr. P.A. Sinu, Central University of Kerala, Kasaragod, Kerala, India

Dr. Afroz Alam, Banasthali Vidyapith (accredited A grade by NAAC), Rajasthan, India

Dr. K.P. Rajesh, Zamorin's Guruvayurappan College, GA College PO, Kozhikode, Kerala, India

Dr. David E. Boufford, Harvard University Herbaria, Cambridge, MA 02138-2020, USA

Dr. Ritesh Kumar Choudhary, Agharkar Research Institute, Pune, Maharashtra, India

Dr. Navendu Page, Wildlife Institute of India, Chandrabani, Dehradun, Uttarakhand, India

Invertebrates

Dr. R.K. Avasthi, Rohtak University, Haryana, India

Dr. D.B. Bastawade, Maharashtra, India

Dr. Partha Pratim Bhattacharjee, Tripura University, Suryamaninagar, India

Dr. Kailash Chandra, Zoological Survey of India, Jabalpur, Madhya Pradesh, India

Dr. Ansie Dippenaar-Schoeman, University of Pretoria, Queenswood, South Africa

Dr. Rory Dow, National Museum of natural History Naturalis, The Netherlands

Dr. Brian Fisher, California Academy of Sciences, USA

Dr. Richard Gallon, llandudno, North Wales, LL30 1UP

Dr. Hemant V. Ghate, Modern College, Pune, India

Dr. M. Monwar Hossain, Jahangirnagar University, Dhaka, Bangladesh

Mr. Jatishwor Singh Irungbam, Biology Centre CAS, Branišovská, Czech Republic

Dr. lan J. Kitching Natural History Museum, Cromwell Road, UK

Dr. George Mathew, Kerala Forest Research Institute, Peechi, India

Dr. John Noyes, Natural History Museum, London, UK

For Focus, Scope, Aims, and Policies, visit https://threatenedtaxa.org/index.php/JoTT/aims_scope
For Article Submission Guidelines, visit https://threatenedtaxa.org/index.php/JoTT/about/submissions
For Policies against Scientific Misconduct, visit https://threatenedtaxa.org/index.php/JoTT/policies_various 


\title{
Wildlife hunting practices of the Santal and Oraon communities in Rajshahi, Bangladesh
}

\section{Azizul Islam Barkat ${ }^{1}$ (D), Fahmida Tasnim Liza ${ }^{2}$ (D), Sumaiya Akter ${ }^{3}$ (D) Ashikur Rahman Shome $^{4}$ (D) \& M. Fazle Rabbe ${ }^{5}$ (iD}

\author{
${ }^{1-5}$ Department of Zoology, University of Dhaka, Nilkhet Road, Dhaka 1000, Bangladesh. \\ ${ }^{5}$ Padma Bridge Museum, Padma Multipurpose Bridge Project, Munshiganj, Bangladesh. \\ ${ }^{1}$ azizulislambarkat@gmail.com, ${ }^{2}$ fahmida_2428@yahoo.com, ${ }^{3}$ sumaiya9267@gmail.com, ${ }^{4}$ shomear61@gmail.com, \\ ${ }^{5}$ fazlerabbedu@gmail.com (corresponding author)
}

\begin{abstract}
Humans have been depending on wild animals from ancient times for food, medicine, economy, tools, and others. Santal and Oraon are two of the indigenous communities present in the Rajshahi district of Bangladesh. They practice wildlife hunting as part of their traditions. We investigated the wildlife hunting practice of these indigenous communities using a closed-ended questionnaire survey. We interviewed 100 households of both communities from four villages. The study indicated that $76 \%$ of respondents hunted ( $88 \%$ Santal and $67 \%$ Oraon); and they usually hunt mammals, birds, reptiles, and amphibians, of which the bird is the most preferred (73\%) and snake the least (1\%). The response of hunting among the two communities significantly differed for tortoise, bird, rabbit, mongoose, jackal, and the Jungle Cat. Eighteen sets of animal taxa were significantly correlated indicating that households exercised preferences in terms of prey. The result also showed that only $14 \%$ of Santal and $7 \%$ of Oraon were familiar with the Bangladesh Wildlife (Conservation and Security) Act, 2012. Although the impact of wildlife hunting of these indigenous groups is still ambiguous, the present study provides a preliminary database of hunting practices of these communities for future conservation management.
\end{abstract}

Keywords: Correlation, hunting material, indigenous community, investigation, questionnaire survey, traditions, wildlife act.

Citation: Barkat, A.I., F.T. Liza, S. Akter, A.R. Shome \& M.F. Rabbe (2021). Wildlife hunting practices of the Santal and Oraon communities in Rajshahi, Bangladesh Journal of Threatened Taxa 13(11): 19484-19491. https://doi.org/10.11609/jott.7260.13.11.19484-19491

Copyright: @ Barkat et al. 2021. Creative Commons Attribution 4.0 International License. JoTT allows unrestricted use, reproduction, and distribution of this article in any medium by providing adequate credit to the author(s) and the source of publication.

Funding: Self-funded.

Competing interests: The authors declare no competing interests. The authors took necessary measures during fieldwork and followed the general ethics throughout the process.

Author details: Azizul Islam Barkat and Sumaiya Akter are enthusiastic researchers majoring in Zoology currently. Ashikur Rahman Shome is a fellow graduate and his field of expertise is Zoology (Wildlife Biology). Fahmida Tasnim Liza is a postgraduate researcher in Zoology, and her research interests extend to wildlife parasitology and conservation. Md. Fazle Rabbe is also a fellow postgraduate who majored in Zoology (Wildlife Biology) and his research interests are biodiversity, wildlife disease and conservation.

Authors contributions: AIB and MFR designed the study and author AIB collected field data. FTL managed the analysis of the study and MFR produced the map. AIB, SA and ARS wrote the first draft of the manuscript. MFR and FTL edited the final version of the manuscript. AIB and MFR contributed equally in the study. All authors read and approved the final manuscript.

Acknowledgements: We express our gratitude to the indigenous communities (Santal \& Oraon) for giving consent and providing necessary information. Special thanks to eminent wildlife expert Dr. Mohammad Firoj Jaman for his continuous encouragement. We thank Mr. Md Rashel Parvez for his company and guidance during the visits to the communities. We thank two anonymous reviewers and subject editor for their valuable comments and improvement of this manuscript. We express our gratitude to Dr. Kerry Kriger and Lana Deaton for revisioning the language of the manuscript. 


\section{INTRODUCTION}

Wildlife has an economic, nutritional, cultural, and ecological role in human society (Chardonnet et al. 2002). Wild animals are a source of food (e.g., protein, fat), medicine, clothes, tools, and adornments as well as rituals and trade (Redford \& Robinson 1991; Stearman \& Redford 1995; Milner-Gulland \& Bennett 2003; Bodmer et al. 2004). However, high rates of wildlife harvest for food and other needs has led to their depletion (Redford \& Robinson 1991). Hunting is considered one among the major threats to wildlife worldwide and cause of species extinction (Aiyadurai 2011).

The southern Asian region is rich in wildlife, but has unsustainable hunting practices (Shackleton 2001; Aiyadurai et al. 2010; Nekaris et al. 2010; Aiyadurai 2011; Velho et al. 2012; Selvan et al. 2013). Communities living near the forest area largely depend on hunting for sustenance and cash income (Wilkie \& Godoy 2001; Albrechtsen et al. 2007; Aiyadurai et al. 2010). Modern hunting technology increases threat to species due to high success rates (Aiyadurai et al. 2010).

Bangladesh is rich in wildlife as its' in the transition zone of the Indo-Himalayan and Indo-Chinese biogeographical regions (IUCN Bangladesh 2015a; Khan 2018). Indigenous communities, which number around 54 , form $1.8 \%$ of the population of Bangladesh (BBS 2011; IWGIA 2019). They primarily rely on forest products for their religious, cultural, and socio-economic needs (Khisa 1998; Ferreira et al. 2009). Hunting is among their traditional practices that has led to the endangerment of several species in Bangladesh (Khisa 1998; Rana et al. 2009; IUCN Bangladesh 2015a; Khan 2018).

Indigenous people in Bangladesh are mainly clustered in the north, northeastern borders, northcentral region, and the greater Chittagong Hill Tracts (Chowdhury et al. 2014). Santal and Oraon are two indigenous communities living in Rajshahi and the surrounding area (Toppo et al. 2016). About 20\% Santal people of Bangladesh are known to live in Rajshahi district whereas the population of Oraon community is increasing (Banglapedia 2014; Shamsuddoha \& Jahan 2018). Every year, wild animals are hunted from char, beel and riparian areas of Rajshahi region. There is little information on how many animals are killed each year (Rana et al. 2009; Alliance 2016; Khan 2018). In this study, we have investigated the hunting practices of the indigenous groups in the Rajshahi district, Bangladesh as well as the correlation among the hunted animals.

\section{MATERIALS AND METHODS}

We conducted a study on wildlife hunting practices of two indigenous groups (Santal and Oraon) in four villages (Zirkupara, Shagrampara, Hazinagar, and Shimla) of Godagari Upazila at Rajshahi district from March to June 2020. The villages have a total of 144 households, and we collected data from 100 houses across all villages using a random sample method (Yates et al. 2008) (Figure 1). In the studied location, only males go hunting. Hence, we interviewed either male or female (if male respondent was absent) from a household and the female respondent was inquired about the male member's hunting habits. To cross-check the female's response, we asked comparable questions to other adult members of the family. Interviews were carried out with the aid of a field assistant who lived in the study area. The questionnaire was entirely close-ended and delivered in Bangla language (see supplementary file). We stayed up to 20 minutes per session to complete each interview mainly on their hunting practices.

We identified the wildlife hunted by the indigenous people through a pilot survey in the study area. We showed them photographic guides of wildlife (Khan 2018) to get an idea about the wildlife species hunted. Most of them could not identify the animal to species level, only as rabbit, jackal, mongoose, and jungle cat. Hence, we sorted the hunted animals into nine groups (Table 1). The respondents were found to be most familiar with mammals rather than other groups (e.g., birds, frogs). Thus, we finalized the questionnaire prioritizing the response of the interviewees by grouping Amphibia as frog, Reptilia as snake and tortoise, Aves as bird, and Mammalia as rabbit, mongoose, jackal, jungle cat, and rat. We sorted the questionnaires in a series of dichotomous (yes-no) questions, with the information of the wildlife being hunted. Besides, we asked interviewees if they actively hunt and if they were familiar with the Wildlife (Conservation and Security) Act, 2012 of Bangladesh.

To compare the hunting preferences and practices of the two communities, we used chi-square test with a 0.05 significance level. We also calculated the association between the hunted animals using Kendall's tau-b coefficient ( $R$ version 1.2.5001). 

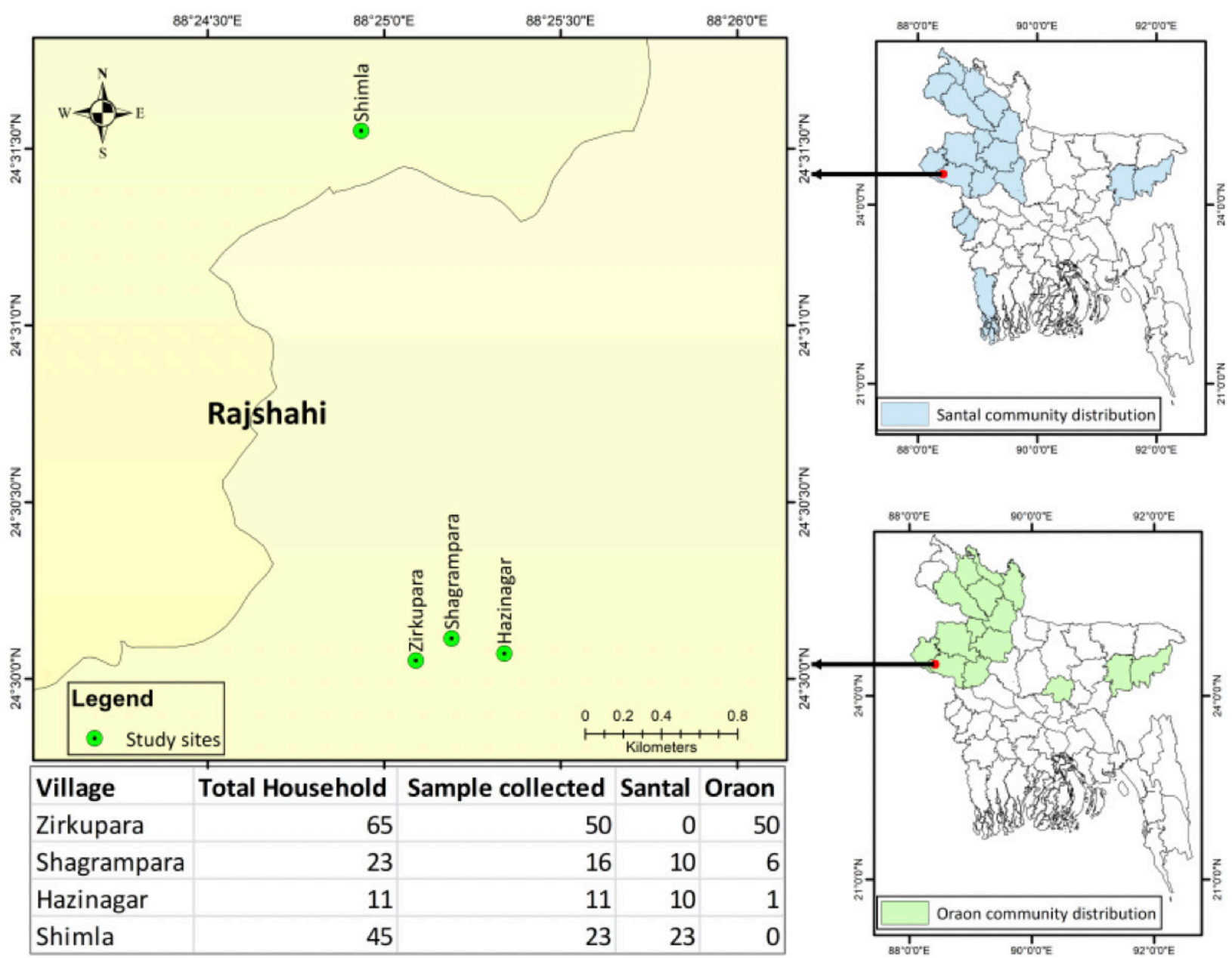

Figure 1. Map of the study area with the current distribution of Santal (Shamsuddoha \& Jahan 2018) and Oraon (Banglapedia 2014) communities in Bangladesh. The table represents the collected sample size for each group with total household number.

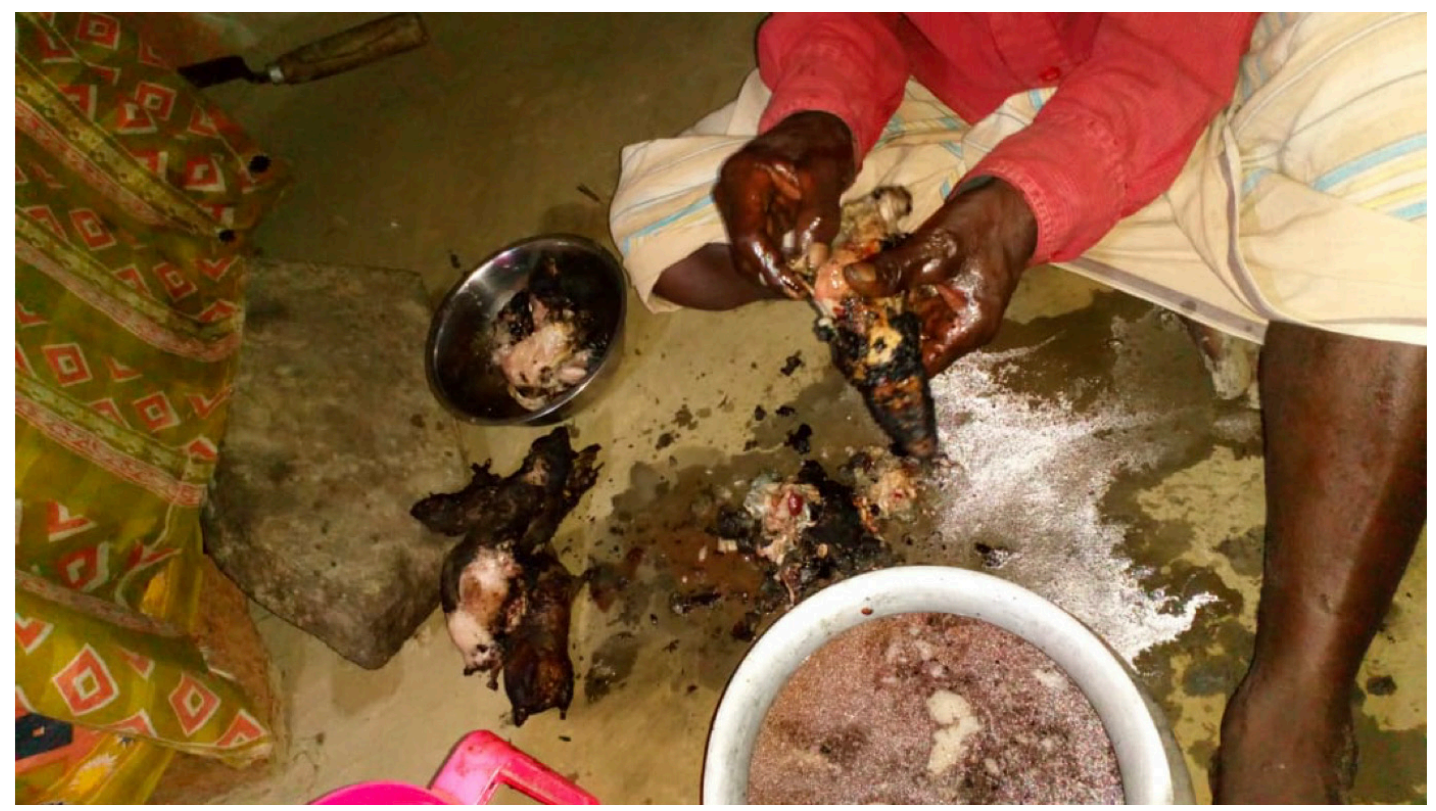

Image 1. Oraon male processing hunted rats for consumption. (C) Azizul Islam Barkat 


\section{RESULTS}

Wildlife hunting practice of the indigenous communities Overall, $76 \%$ of respondents $188.37 \%$ Santal \& $66.67 \%$ Oraon) responded positively in the question of going hunting. The response varied significantly in two indigenous communities $\left(\chi^{2}=6.331, p=0.012\right)$. Among the nine animal groups, bird (73\%) was the most hunted while snake (1\%) was the least. Of the herpetofaunal animal groups, only $5 \%$ interviewees were found to hunt frogs, and $64 \%$ to hunt tortoises. We found rats as the most hunted mammal group (61\%) and jackals the least (6\%). Among other mammals, $44 \%$ of respondents hunted mongoose, $31 \%$ jungle cats, and $28 \%$ rabbits (Figure 2).

The positive responses of Santal and Oraon were significantly varied for hunting tortoise $(p=0.006)$, bird $(p=0.036)$, rabbit $(p<0.000)$, mongoose $(p<0.000)$, jackal $(p=0.040)$, and jungle cat $(p<0.000)$ (Table 1$)$. In questioning whether they know about the Wildlife (Conservation and Security) Act, 2012, we found no significant difference among the indigenous groups $\left(\chi^{2}=\right.$ $1.310, p=0.252)$. Only 10 respondents (13.95\% Santal \& $7.02 \%$ Oraon) knew about the act but not many details of it.

\section{Correlation of hunting different wildlife groups}

Table 2 represents the correlation of hunting animals that consists of 36 pairs. The dual-trail verification showed that 18 pairs are significantly correlated. The correlativity of hunting 'mongoose' and 'jungle cat' demonstrates the maximum of ' 0.626 '; indicating a significant fairly large overlap in hunting these two wildlife groups. The second highest value (0.545) of correlation is found for 'jungle cat' and 'rabbit' hunting. We also found some negative correlation pairs among the groups (e.g., jungle cat-frog, jungle cat-snake, ratjackal).

\section{DISCUSSION}

The result showed that birds are most vulnerable to hunting (Figure 2). Among wild birds, doves (Spilopelia spp., Streptopelia spp.) are mostly hunted because of their availability and ease of capture. Besides, wild birds are a free source of meat. Locals hunt them with a variety of hunting materials such as catapults, snares, traps, and baits. Other indigenous communities in Bangladesh also use these techniques to hunt birds (Chowdhury et al. 2007, 2014). Besides, locals often steal chicks and juvenile from nests. Hunting, poisoning, and trapping of birds remain a big threat despite the strong law and popular sentiment against it (IUCN Bangladesh 2015b).

We found neither Santal nor Oraon are habituated to eating herpetofauna (excluding tortoises). We assume that locals do not regard herpetofauna as a good source of protein. But, in India both the indigenous groups eat snakes, frogs, and other herps (Ghosh-Jerath et al. $2015,2016)$. We found only $5 \%$ ( $1 \%$ Santal \& 4\% Oraon) people eating frogs, $1 \%$ eating snakes and these did not differ significantly between the two communities (Table 1). For tortoises, the result showed a significant difference between the indigenous groups $(p=0.006)$. Tortoises used to be hunted on a regular basis, but their population number have suddenly plummeted in the area. So, locals either search for these animals in nearby habitats or purchase them from markets

Table 1. Wildlife hunting practices of the two indigenous groups with a list of animals hunted in the study area.

\begin{tabular}{|c|c|c|c|c|c|}
\hline \multirow[b]{2}{*}{ Genus/Species name } & \multirow[b]{2}{*}{ Group } & \multirow[b]{2}{*}{ Class } & \multirow[b]{2}{*}{$x^{2}$} & \multicolumn{2}{|c|}{ Yes (percentage) } \\
\hline & & & & Oraon $(n=57)$ & Santal $(n=43)$ \\
\hline Hoplobatrachus spp. & Frog & Amphibia & 1.136 & $4(7.01)$ & $1(2.33)$ \\
\hline Naja spp. & Snake & \multirow{2}{*}{ Reptilia } & 0.762 & $1(1.75)$ & $0(0)$ \\
\hline $\begin{array}{l}\text { Morenia petersi, Nilssonia spp., Pangshura spp., Lissemys } \\
\text { punctata }\end{array}$ & Tortoise $^{\#}$ & & $7.436^{* *}$ & $30(52.63)$ & $34(79.07)$ \\
\hline $\begin{array}{l}\text { Spilopelia sp., Streptopelia spp., Ardeola grayii, Ardea spp., } \\
\text { Amaurornis phoenicurus, Acridotheres spp., Passer sp., } \\
\text { Microcarbo niger }\end{array}$ & Bird & Aves & $4.399^{*}$ & $37(64.91)$ & $36(83.72)$ \\
\hline Lepus nigricollis & Rabbit & \multirow{5}{*}{ Mammalia } & $33.992 * * *$ & $3(5.26)$ & $25(58.14)$ \\
\hline Herpestes edwardsii & Mongoose & & $24.163^{* * *}$ & $13(22.81)$ & $31(72.09)$ \\
\hline Canis aureus & Jackal & & $4.237^{*}$ & $1(1.75)$ & $5(11.63)$ \\
\hline Felis chaus & Jungle cat & & $41.049 * * *$ & $3(5.26)$ & $28(65.12)$ \\
\hline Rattus spp., Bandicota spp. & Rat & & 0.853 & $37(64.91)$ & $24(55.81)$ \\
\hline
\end{tabular}

Tortoise $(*)$ is the only group that is either consumed by hunting or buying from nearby markets. $p$-value is represented in asterisk $\left({ }^{*} p \leq 0.05, * * p \leq 0.01, * * * p \leq 0.001\right)$. 


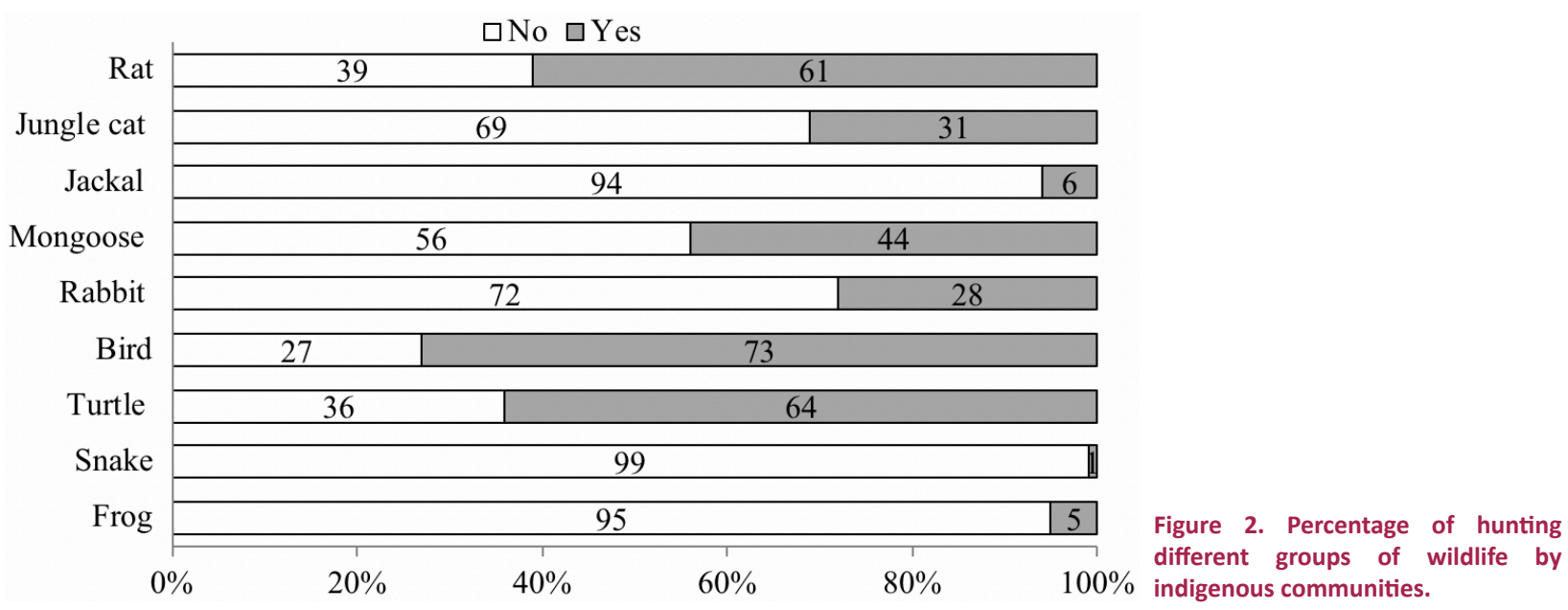

Table 2. Kendall's tau-b coefficient results in hunting different groups of wildlife with p-value in asterisk mark.

\begin{tabular}{|c|c|c|c|c|c|c|c|c|}
\hline Groups & Snake & Tortoise & Bird & Rabbit & Mongoose & Jackal & Jungle cat & Rat \\
\hline Frog & $\begin{array}{c}0.438 \\
* * *\end{array}$ & 0.172 & 0.140 & 0.061 & 0.166 & $\begin{array}{c}0.328 \\
* * *\end{array}$ & -0.055 & 0.183 \\
\hline Snake & & 0.075 & 0.061 & 0.161 & 0.113 & $\begin{array}{c}0.398 \\
* * *\end{array}$ & -0.067 & 0.08 \\
\hline Tortoise & & & $\begin{array}{c}0.295 \\
* *\end{array}$ & $\begin{array}{c}0.282 \\
* *\end{array}$ & $\begin{array}{c}0.413 \\
* * *\end{array}$ & 0.014 & $0.232 *$ & $\begin{array}{c}0.425 \\
* * *\end{array}$ \\
\hline Bird & & & & $0.221 *$ & $0.221^{*}$ & 0.059 & $0.213^{*}$ & 0.068 \\
\hline Rabbit & & & & & $\begin{array}{c}0.479 \\
* * *\end{array}$ & $0.218^{*}$ & $\begin{array}{c}0.545 \\
* * *\end{array}$ & 0.179 \\
\hline Mongoose & & & & & & $0.200^{*}$ & $\begin{array}{c}0.626 \\
* * *\end{array}$ & $0.296^{* *}$ \\
\hline Jackal & & & & & & & $\begin{array}{c}0.286 \\
* *\end{array}$ & -0.057 \\
\hline Jungle cat & & & & & & & & 0.181 \\
\hline
\end{tabular}

$\left({ }^{*} p \leq 0.05, * * p \leq 0.01, * * * p \leq 0.001\right)$

(BDT 700-800 per kilogram). Because of the high price, many cannot afford it and thus, actively go for tortoise hunting. Tortoises are highly-priced for both food and medicinal value (Harrison et al. 2016). Other than nutritional value, we also observed that people of these indigenous communities believe tortoise flesh has curative properties. They believe, it improves vision and keeping tortoise bone in cattle's feeding pot can heal foot and mouth diseases of cattle. Tortoise is also hunted by other indigenous communities such as Mro in Chittagong hill tracts of Bangladesh (Chowdhury et al. 2007, 2014).

Among mammals, rats are hunted mostly by the locals and there is no specific season for rat hunting (Image 1). The indigenous people hunt rats if they find them while working in cultivated land. However, they hunt the animal in huge number after harvesting the crops, so it becomes easier to look for rat nests or holes.
We found that $55.81 \%$ Santal and $64.91 \%$ Oraon hunt rats for meat but their response was not significantly different (Table 1). This practice can lead to decreased use of rodenticides and not hunt the other ecologically useful wild species (Meyer-Rochow et al. 2015).

The hunting percentage for other mammals (except rats) differed significantly among the two communities (Table 1). Table 1 also shows that Santals prefer hunting mammals (e.g., jackal, rabbit, jungle cat) than Oraons. For example, $58.14 \%$ of Santal participated in rabbit hunting, whereas only $5.26 \%$ of Oraon did. Both communities go for traditional hunting early or late in the winter season. They generally go hunting in char lands, the adjacent area of their settlements, and nearest districts (e.g., Chapainawabganj) but sometimes, they travel further away to other districts (e.g., Naogaon, Joypurhat, Bogura, Kushtia, Pabna, Khulna) for 2-7 days. When they travel a long distance, they use turmeric powder on 
skinned prey for preservation. Usually, they go hunting with traditional arms (bow \& arrow) in winter (Image 2) (Aiyadurai et al. 2010; IUCN Bangladesh 2015b).

We found that the majority of Santals are hunters (88.37\%). Hunting is a common source of animal protein for their households. The studies of Sarker et al. (2017) and Das (2011) showed that Santals are very skilled in hunting different wildlife species (e.g., rats, birds, snakes) in Bangladesh though they are facing vulnerability in present times due to deforestation. Thus, they have started cultivating agricultural lands for livelihood. The Oraon community (66.67\%) also harvests wildlife as well, but to a lesser extent than the Santal community. We observed during the survey that although most of the Oraon people are farmers, still a portion has selected other jobs and businesses that reduce their need to go hunting. Besides, the household members with higher economic status are more knowledgeable about wildlife conservation issues than others (Randolph et al. 2007).

Many studies on hunting showed correlation with different factors, like- number of hunters and catch (e.g., Nielsen 2006); distance and hunting rate (e.g., Chutia 2010); hunted species and body weight (e.g., Constantino 2016). We calculated the relationship of hunting different groups of wildlife in this study. The result showed a significant hunting relationship between two carnivores (mongoose-jungle cat). Small carnivores have similar habits and live in similar types of habitats (Chutipong et al. 2017). Hunters can easily hunt multiple species in similar habitats spending minimum effort. The relationship signified that hunters' response in hunting one of these species increases the chance of hunting the other one and vice versa. The negative relationship among other groups such as jungle cat-frog also supports our explanation.

The present study revealed that only $10 \%$ of the respondents were familiar with Bangladesh Wildlife Act 2012, as most of the older people of Santal and Oraon are uneducated or illiterate. They were even unaware that hunting wildlife is a crime. We found very few respondents who keep certificates of hunting permission from the police station or union chairman so they can go hunting. But, they could not show us any kind of certificates during the survey. Higher education is still lacking along with the workshops on wildlife hunting and conservation on behalf of the government. Because it is seen that the more these communities are educated, the more they are aware of wildlife conservation (Kaltenborn et al. 1999).

\section{CONCLUSIONS}

Indigenous communities harvest wild animals worldwide for different purposes which constitute essential ingredients in daily livelihoods (Ferreira et al. 2009). Santal and Oraon are two closely related indigenous communities of Bangladesh that rely on agricultural day labor. They are unable to buy meat from markets due to their poverty. As a result, they are compelled to hunt wildlife, especially for animal protein consumption. Again, it is seen that they go hunting whenever they are free or jobless. However, many of the respondents of this study also think that the wildlife population is declining due to hunting. We recommend some measures for the conservation of hunted animals in the area.

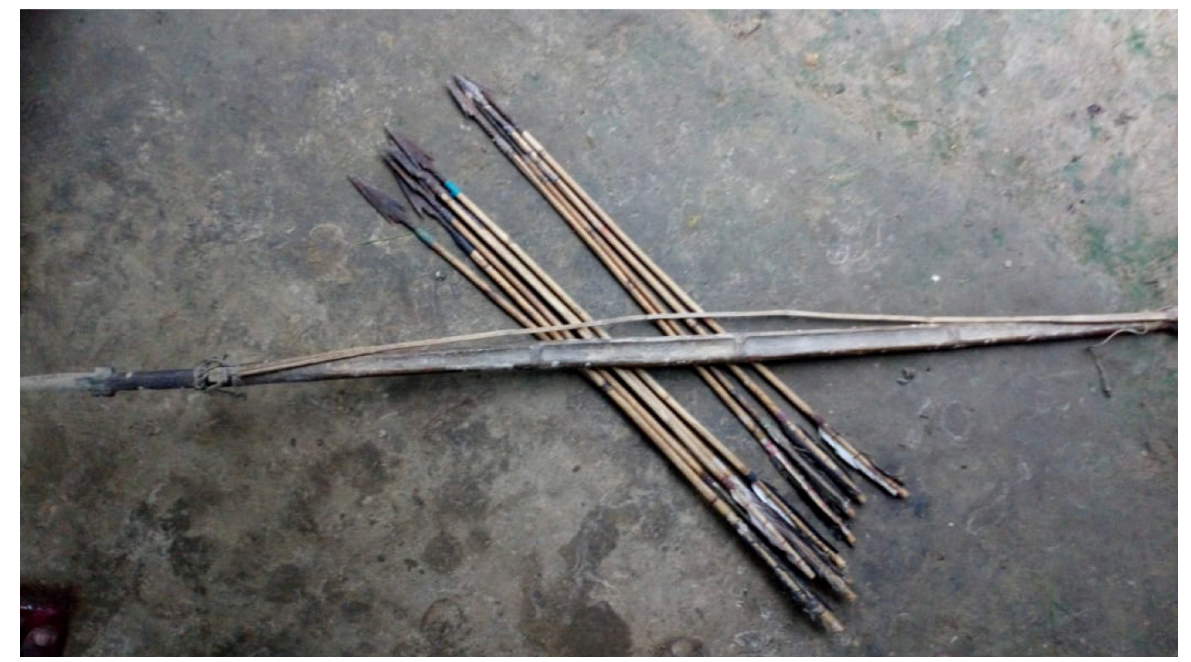

Image 2. Bow and arrow for hunting mammals like Jungle Cat and Jackal. (C) Azizul Islam Barkat 
1. According to Bangladesh Wildlife (Conservation and Security) Act, 2012, wildlife hunting is a punishable offence; hence the law should be executed strictly to prevent illegal hunting. The government can impose a coordination committee to facilitate the quick execution of the existing law.

2. The respective authorities have to ensure the availability of suitable jobs (e.g., agro-farming, agribusiness) for indigenous people throughout the year.

3. Conservation education and awareness about wildlife should be disseminated among all the stakeholders for future wildlife conservation purposes and management.

4. Existing natural habitats should be conserved and more emphasis should be imposed to ensure undisturbed breeding and feeding grounds.

\section{REFERENCES}

Aiyadurai, A. (2011). Wildlife hunting and conservation in Northeas India: a need for an interdisciplinary understanding. Internationa Journal of Galliformes Conservation 2: 61-73.

Aiyadurai, A., N.J. Singh \& E.J. Milner-Gulland (2010). Wildlife hunting by indigenous tribes: a case study from Arunachal Pradesh north-east India. Oryx 44(4): 564-572. https://doi.org/10.1017/ S0030605309990937

Albrechtsen, L., D.W. Macdonald, P.J. Johnson, R. Castelo \& J.E. Fa (2007). Faunal loss from bushmeat hunting: empirical evidence and policy implications in Bioko Island. Environmental Science \& Policy 10(7-8): 654-667. https://doi.org/10.1016/j. envsci.2007.04.007

Alliance, C.C. (2016). A preliminary wildlife survey in Sangu-Matamuhuri Reserve Forest, Chittagong Hill Tracts, Bangladesh. Unpublished report submitted to Bangladesh Forest Department, Dhaka, Bangladesh, 52pp

BBS (2011). Population and housing census 2011. Bangladesh Bureau of Statistics, Government of the Peoples' Republic of Bangladesh, Dhaka, 3 pp.

Banglapedia (2014). Banglapedia, National Encyclopedia of Bangladesh. Accessed in 15 June 2021. Available at http:// en.banglapedia.org/index.php/Oraon,_The

Bodmer, R.E., E.P. Lozano \& T.G. Fang. (2004). Economic Analysis of Wildlife Use in the Peruvian Amazon, pp. 191-208. In: Silvius, K.M., R.E. Bodmer \& J.M.V. Fragoso (eds). People in Nature. Columbia University Press, 464pp. https://doi.org/10.7312/silv12782-012

Chardonnet, P., B.D. Clers, J. Fischer, R. Gerhold, F. Jori \& F. Lamarque (2002). The value of wildlife. Revue scientifique et technique-Office international des épizooties 21(1): 15-52. https://doi.org/10.20506/ rst.21.1.1323

Chowdhury, M.S.H., M.A. Halim, M.D. Miah, N. Muhammed \& M. Koike (2007). Research communication: biodiversity use through harvesting faunal resources from forests by the Mro tribe in the Chittagong Hill Tracts, Bangladesh. The International Journal of Biodiversity Science and Management 3(1): 56-62. https://doi. org/10.1080/17451590709618162

Chowdhury, M.S.H., S. Izumiyama, N. Nazia, N. Muhammed \& M. Koike (2014). Dietetic use of wild animals and traditional cultural beliefs in the Mro community of Bangladesh: an insight into biodiversity conservation. Biodiversity 15(1): 23-38. https://doi.or g/10.1080/14888386.2014.893201

Chutia, P. (2010). Studies on hunting and the conservation of wildlife species in Arunachal Pradesh. Sibcoltejo 5(2010): 56-67.

Chutipong, W., R. Steinmetz, T, Savini \& G.A. Gale (2017). Assessing resource and predator effecs on habitat use of tropical small carnivors. Mammal Research 62(1): 21-36. https://doi.org/10.1007/ 13364-016-0283-z

Constantino, P. (2016). Deforestation and hunting effects on wildlife across Amazonian indigenous lands. Ecology and Society 21(2): 3. https://doi.org/10.5751/ES-08323-210203

Das, S. (2011). Indigenous people's access to land in Northern-belt of Bangladesh: a study of the Santal community. Master's thesis, Universitetet i Troms $\varnothing$. https://munin.uit.no/handle/10037/3471

Ferreira, F.S., S.V. Brito, S.C. Ribeiro, W.O. Almeida \& R.R. Alves (2009). Zootherapeutics utilized by residents of the community Poco Dantas, Crato-CE, Brazil. Journal of Ethnobiology and Ethnomedicine 5(1): 1-10. https://doi.org/10.1186/1746-4269-5-21

Ghosh-Jerath, S., A. Singh, M.S. Magsumbol, T. Lyngdoh, P. Kamboj \& G. Goldberg (2016). Contribution of indigenous foods towards nutrient intakes and nutritional status of women in the Santhal tribal community of Jharkhand, India. Public health nutrition 19(12): 2256-2267. https://doi.org/10.1017/S1368980016000318

Ghosh-Jerath, S., A. Singh, P. Kamboj, G. Goldberg \& M.S. Magsumbol (2015). Traditional knowledge and nutritive value of indigenous foods in the Oraon tribal community of Jharkhand: an exploratory cross-sectional study. Ecology of Food and Nutrition 54(5): 493-519. https://doi.org/10.1080/03670244.2015.1017758

Harrison, R.D., R. Sreekar, J.F. Brodie, S. Brook, M. Luskin, H. O'Kelly, M. Rao, B. Scheffers \& N. Velho (2016). Impacts of hunting on tropical forests in Southeast Asia. Conservation Biology 30(5): 972981. https://doi.org/10.1111/cobi.12785

International Work Group for Indigenous Affairs (IWGIA). (2019). Indigenous World 2019: Bangladesh. https://www.iwgia.org/en/ bangladesh/3446-iw2019-bangladesh.html

IUCN Bangladesh (2015a). Red List of Bangladesh Volume 2: Mammals. IUCN, International Union for Conservation of Nature, Bangladesh Country Office, Dhaka, Bangladesh, 49pp.

IUCN Bangladesh (2015b). Red List of Bangladesh Volume 3: Birds. IUCN, International Union for Conservation of Nature, Bangladesh Country Office, Dhaka, Bangladesh, 45pp.

Kaltenborn, B.P., T. Bjerke \& J. Vitterso (1999). Attitudes toward large carnivores among sheep farmers, wildlife managers, and research biologists in Norway. Human Dimensions of Wildlife 4(1): 57-73. https://doi.org/10.1080/10871209909359142

Khan, M.M.H. (2018). A Photographic Guide to Wildlife of Bangladesh. Arannayk Foundation, Dhaka, Bangladesh, 488pp.

Khisa, S.K. (1998). Ethno-botanical cultural background of ethnic communities in forest resource management in Chittagong Hill Tracts, pp. 56-63. In: Banik, R.L., M.K. Alam, S.J. Pei, \& A. Rastog (eds.). Applied Ethnobotany. Chittagong: Bangladesh Forest Research Institute.

Meyer-Rochow, V.B., K. Megu \& J. Chakravorty (2015). Rats: if you can't beat them eat them! (Tricks of the trade observed among the Adi and other North-East Indian tribals). Journal of Ethnobiology and Ethnomedicine 11(2): 1-12. https://doi.org/10.1186/s13002015-0034-2

Milner-Gulland, E.J. \& E.L. Bennett (2003). Wild meat: the bigger picture. Trends in Ecology \& Evolution 18(10): 351-357. https://doi. org/10.1016/S0169-5347(03)00123-X

Nekaris, K.A.I., C.R. Shepherd, C.R. Starr \& V. Nijman (2010). Exploring cultural drivers for wildlife trade via an ethnoprimatological approach: a case study of slender and slow lorises (Loris and Nycticebus) in South and Southeast Asia. American Journal of Primatology 72(10): 877-886. https://doi.org/10.1002/ajp.20842

Nielsen, M.R. (2006). Importance, cause and effect of bushmeat hunting in the Udzungwa Mountains, Tanzania: Implications for community based wildlife management. Biological conservation 128(4): 509-516. https://doi.org/10.1016/j.biocon.2005.10.017

Rana, M.P., M.S.I. Sohel, S. Akhter \& M.R. Hassan (2009). Indigenous Food Habit of the Hajong Tribe Community in Bangladesh: Implication for Sustainable Extraction and Biodiversity Conservation 
in North-East Bangladesh. Journal of Forest and Environmental Science 25(2): 101-109. https://www.earticle.net/Article/A114942

Randolph, T.F., E. Schelling, D. Grace, C.F. Nicholson, J.L. Leroy, D.C. Cole \& M. Ruel (2007). Invited review: Role of livestock in human nutrition and health for poverty reduction in developing countries. Journal of Animal Science 85(11): 2788-2800. https://doi. org/10.2527/jas.2007-0467

Redford, K.H. \& J.G. Robinson (1991). Subsistence and commercial uses of wildlife in Latin America. Neotropical Wildlife Use and Conservation 6: 23.

Sarker, M.A.R., N.A. Khan \& K.M. Musarrat (2017). Livelihood and vulnerability of the Santals community in Bangladesh. The Malaysian Journal of Social Administration 12(1): 38-55. https:// doi.org/10.22452/mjsa.vol12no1.2

Selvan, K.M., G.G. Veeraswami, B. Habib \& S. Lyngdoh (2013). Losing threatened and rare wildlife to hunting in Ziro Valley, Arunachal Pradesh, India. Current Science 104(11): 1492-1495. https://www. jstor.org/stable/24092472

Shackleton, D.M. (2001). A review of community-based trophy hunting programs in Pakistan. IUCN, the World Conservation Union.

Shamsuddoha, M. \& M.R. Jahan (2018). Santal Community in
Bangladesh: A Socio-historical Analysis. Asian Journal of Humanity, Art and Literature 5(2): 89-100. https://doi.org/10.18034/ajhal. v5i2.339

Stearman, A.M. \& K.H. Redford (1995). Game management and cultural survival: the Yuquí ethnodevelopment project in lowland Bolivia. Oryx 29(1): 29-34. https://doi.org/10.1017/ S0030605300020846

Toppo, A., M.R. Rahman, M.Y. Ali \& A. Javed (2016). The socioeconomic condition of plain land tribal people in Bangladesh. Social Sciences 5(4): 58-63. https://doi.org/10.11648/j.ss.20160504.12

Velho, N., K.K. Karanth \& W.F. Laurance (2012). Hunting: A serious and understudied threat in India, a globally significant conservation region. Biological Conservation 148(1): 210-215. https://doi. org/10.1016/j.biocon.2012.01.022

Wilkie, D.S. \& R.A. Godoy (2001). Income and price elasticities of bushmeat demand in lowland Amerindian societies. Conservation Biology 15(3): 761-769. https://doi.org/10.1046/j.15231739.2001.015003761.x

Yates, D.S., D.S. Starnes \& D.S. Moore (2008). The Practice of Statistics. Research design: Qualitative, quantitative, and mixed method approaches. W.H. Freeman, 858pp. 
Dr. Albert G. Orr, Griffith University, Nathan, Australia

Dr. Sameer Padhye, Katholieke Universiteit Leuven, Belgium

Dr. Nancy van der Poorten, Toronto, Canada

Dr. Kareen Schnabel, NIWA, Wellington, New Zealand

Dr. R.M. Sharma, (Retd.) Scientist, Zoological Survey of India, Pune, India

Dr. Manju Siliwal, WILD, Coimbatore, Tamil Nadu, India

Dr. G.P. Sinha, Botanical Survey of India, Allahabad, India

Dr. K.A. Subramanian, Zoological Survey of India, New Alipore, Kolkata, India

Dr. P.M. Sureshan, Zoological Survey of India, Kozhikode, Kerala, India

Dr. R. Varatharajan, Manipur University, Imphal, Manipur, India

Dr. Eduard Vives, Museu de Ciències Naturals de Barcelona, Terrassa, Spain

Dr. James Young, Hong Kong Lepidopterists' Society, Hong Kong

Dr. R. Sundararaj, Institute of Wood Science \& Technology, Bengaluru, India

Dr. M. Nithyanandan, Environmental Department, La Ala Al Kuwait Real Estate. Co. K.S.C., Kuwait

Dr. Himender Bharti, Punjabi University, Punjab, India

Mr. Purnendu Roy, London, UK

Dr. Saito Motoki, The Butterfly Society of Japan, Tokyo, Japan

Dr. Sanjay Sondhi, TITLI TRUST, Kalpavriksh, Dehradun, India

Dr. Nguyen Thi Phuong Lien, Vietnam Academy of Science and Technology, Hanoi, Vietnam

Dr. Nitin Kulkarni, Tropical Research Institute, Jabalpur, India

Dr. Robin Wen Jiang Ngiam, National Parks Board, Singapore

Dr. Lional Monod, Natural History Museum of Geneva, Genève, Switzerland.

Dr. Asheesh Shivam, Nehru Gram Bharti University, Allahabad, India

Dr. Rosana Moreira da Rocha, Universidade Federal do Paraná, Curitiba, Brasil

Dr. Kurt R. Arnold, North Dakota State University, Saxony, Germany

Dr. James M. Carpenter, American Museum of Natural History, New York, USA

Dr. David M. Claborn, Missouri State University, Springfield, USA

Dr. Kareen Schnabel, Marine Biologist, Wellington, New Zealand

Dr. Amazonas Chagas Júnior, Universidade Federal de Mato Grosso, Cuiabá, Brasil

Mr. Monsoon Jyoti Gogoi, Assam University, Silchar, Assam, India

Dr. Heo Chong Chin, Universiti Teknologi MARA (UiTM), Selangor, Malaysia

Dr. R.J. Shiel, University of Adelaide, SA 5005, Australia

Dr. Siddharth Kulkarni, The George Washington University, Washington, USA

Dr. Priyadarsanan Dharma Rajan, ATREE, Bengaluru, India

Dr. Phil Alderslade, CSIRO Marine And Atmospheric Research, Hobart, Australia

Dr. John E.N. Veron, Coral Reef Research, Townsville, Australia

Dr. Daniel Whitmore, State Museum of Natural History Stuttgart, Rosenstein, Germany.

Dr. Yu-Feng Hsu, National Taiwan Normal University, Taipei City, Taiwan

Dr. Keith V. Wolfe, Antioch, California, USA

Dr. Siddharth Kulkarni, The Hormiga Lab, The George Washington University, Washington,

D.C., USA

Dr. Tomas Ditrich, Faculty of Education, University of South Bohemia in Ceske

Budejovice, Czech Republic

Dr. Mihaly Foldvari, Natural History Museum, University of Oslo, Norway

Dr. V.P. Uniyal, Wildlife Institute of India, Dehradun, Uttarakhand 248001, India

Dr. John T.D. Caleb, Zoological Survey of India, Kolkata, West Bengal, India

Dr. Priyadarsanan Dharma Rajan, Ashoka Trust for Research in Ecology and the Environment (ATREE), Royal Enclave, Bangalore, Karnataka, India

\section{Fishes}

Dr. Neelesh Dahanukar, IISER, Pune, Maharashtra, India

Dr. Topiltzin Contreras MacBeath, Universidad Autónoma del estado de Morelos, México

Dr. Heok Hee Ng, National University of Singapore, Science Drive, Singapore

Dr. Rajeev Raghavan, St. Albert's College, Kochi, Kerala, India

Dr. Robert D. Sluka, Chiltern Gateway Project, A Rocha UK, Southall, Middlesex, UK

Dr. E. Vivekanandan, Central Marine Fisheries Research Institute, Chennai, India

Dr. Davor Zanella, University of Zagreb, Zagreb, Croatia

Dr. A. Biju Kumar, University of Kerala, Thiruvananthapuram, Kerala, India

Dr. Akhilesh K.V., ICAR-Central Marine Fisheries Research Institute, Mumbai Research

Centre, Mumbai, Maharashtra, India

Dr. J.A. Johnson, Wildlife Institute of India, Dehradun, Uttarakhand, India

\section{Amphibians}

Dr. Sushil K. Dutta, Indian Institute of Science, Bengaluru, Karnataka, India

Dr. Annemarie Ohler, Muséum national d'Histoire naturelle, Paris, France

\section{Reptiles}

Dr. Gernot Vogel, Heidelberg, Germany

Dr. Raju Vyas, Vadodara, Gujarat, India

Dr. Pritpal S. Soorae, Environment Agency, Abu Dubai, UAE.

Prof. Dr. Wayne J. Fuller, Near East University, Mersin, Turkey

Prof. Chandrashekher U. Rivonker, Goa University, Taleigao Plateau, Goa. India

Dr. S.R. Ganesh, Chennai Snake Park, Chennai, Tamil Nadu, India

Dr. Himansu Sekhar Das, Terrestrial \& Marine Biodiversity, Abu Dhabi, UAE
Birds

Dr. Hem Sagar Baral, Charles Sturt University, NSW Australia

Dr. Chris Bowden, Royal Society for the Protection of Birds, Sandy, UK

Dr. Priya Davidar, Pondicherry University, Kalapet, Puducherry, India

Dr. J.W. Duckworth, IUCN SSC, Bath, UK

Dr. Rajah Jayapal, SACON, Coimbatore, Tamil Nadu, India

Dr. Rajiv S. Kalsi, M.L.N. College, Yamuna Nagar, Haryana, India

Dr. V. Santharam, Rishi Valley Education Centre, Chittoor Dt., Andhra Pradesh, India

Dr. S. Balachandran, Bombay Natural History Society, Mumbai, India

Mr. J. Praveen, Bengaluru, India

Dr. C. Srinivasulu, Osmania University, Hyderabad, India

Dr. K.S. Gopi Sundar, International Crane Foundation, Baraboo, USA

Dr. Gombobaatar Sundev, Professor of Ornithology, Ulaanbaatar, Mongolia

Prof. Reuven Yosef, International Birding \& Research Centre, Eilat, Israel

Dr. Taej Mundkur, Wetlands International, Wageningen, The Netherlands

Dr. Carol Inskipp, Bishop Auckland Co., Durham, UK

Dr. Tim Inskipp, Bishop Auckland Co, Durham, UK

Dr. V. Gokula, National College, Tiruchirappalli, Tamil Nadu, India

Dr. Arkady Lelej, Russian Academy of Sciences, Vladivostok, Russia

Dr. Simon Dowell, Science Director, Chester Zoo, UK

Dr. Mário Gabriel Santiago dos Santos, Universidade de Trás-os-Montes e Alto Douro,

Quinta de Prados, Vila Real, Portugal

Dr. Grant Connette, Smithsonian Institution, Royal, VA, USA

Dr. M. Zafar-ul Islam, Prince Saud Al Faisal Wildlife Research Center, Taif, Saudi Arabia

Mammals

Dr. Giovanni Amori, CNR - Institute of Ecosystem Studies, Rome, Italy

Dr. Anwaruddin Chowdhury, Guwahati, India

Dr. David Mallon, Zoological Society of London, UK

Dr. Shomita Mukherjee, SACON, Coimbatore, Tamil Nadu, India

Dr. Angie Appel, Wild Cat Network, Germany

Dr. P.O. Nameer, Kerala Agricultural University, Thrissur, Kerala, India

Dr. Ian Redmond, UNEP Convention on Migratory Species, Lansdown, UK

Dr. Heidi S. Riddle, Riddle's Elephant and Wildlife Sanctuary, Arkansas, USA

Dr. Karin Schwartz, George Mason University, Fairfax, Virginia.

Dr. Lala A.K. Singh, Bhubaneswar, Orissa, India

Dr. Mewa Singh, Mysore University, Mysore, India

Dr. Paul Racey, University of Exeter, Devon, UK

Dr. Honnavalli N. Kumara, SACON, Anaikatty P.O., Coimbatore, Tamil Nadu, India

Dr. Nishith Dharaiya, HNG University, Patan, Gujarat, India

Dr. Spartaco Gippoliti, Socio Onorario Società Italiana per la Storia della Fauna "Giuseppe

Altobello", Rome, Italy

Dr. Justus Joshua, Green Future Foundation, Tiruchirapalli, Tamil Nadu, India

Dr. H. Raghuram, The American College, Madurai, Tamil Nadu, India

Dr. Paul Bates, Harison Institute, Kent, UK

Dr. Jim Sanderson, Small Wild Cat Conservation Foundation, Hartford, USA

Dr. Dan Challender, University of Kent, Canterbury, UK

Dr. David Mallon, Manchester Metropolitan University, Derbyshire, UK

Dr. Brian L. Cypher, California State University-Stanislaus, Bakersfield, CA

Dr. S.S. Talmale, Zoological Survey of India, Pune, Maharashtra, India

Prof. Karan Bahadur Shah, Budhanilakantha Municipality, Kathmandu, Nepal

Dr. Susan Cheyne, Borneo Nature Foundation International, Palangkaraja, Indonesia

Dr. Hemanta Kafley, Wildlife Sciences, Tarleton State University, Texas, USA

\section{Other Disciplines}

Dr. Aniruddha Belsare, Columbia MO 65203, USA (Veterinary)

Dr. Mandar S. Paingankar, University of Pune, Pune, Maharashtra, India (Molecular)

Dr. Jack Tordoff, Critical Ecosystem Partnership Fund, Arlington, USA (Communities)

Dr. Ulrike Streicher, University of Oregon, Eugene, USA (Veterinary)

Dr. Hari Balasubramanian, EcoAdvisors, Nova Scotia, Canada (Communities)

Dr. Rayanna Hellem Santos Bezerra, Universidade Federal de Sergipe, São Cristóvão, Brazil

Dr. Jamie R. Wood, Landcare Research, Canterbury, New Zealand

Dr. Wendy Collinson-Jonker, Endangered Wildlife Trust, Gauteng, South Africa

Dr. Rajeshkumar G. Jani, Anand Agricultural University, Anand, Gujarat, India

Dr. O.N. Tiwari, Senior Scientist, ICAR-Indian Agricultural Research Institute (IARI), New

Delhi, India

Dr. L.D. Singla, Guru Angad Dev Veterinary and Animal Sciences University, Ludhiana, India

Dr. Rupika S. Rajakaruna, University of Peradeniya, Peradeniya, Sri Lanka

Dr. Bahar Baviskar, Wild-CER, Nagpur, Maharashtra 440013, India

Reviewers 2018-2020

Due to pausity of space, the list of reviewers for 2018-2020 is available online.
The opinions expressed by the authors do not reflect the views of the Journal of Threatened Taxa, Wildlife Information Liaison Development Society, Zoo Outreach Organization, or any of the partners. The journal, the publisher, the host, and the partners are not responsible for the accuracy of the political boundaries shown in the maps by the authors.

\footnotetext{
Print copies of the Journal are available at cost. Write to:

The Managing Editor, JoTT,

c/o Wildlife Information Liaison Development Society,

No. 12, Thiruvannamalai Nagar, Saravanampatti - Kalapatti Road,

Saravanampatti, Coimbatore, Tamil Nadu 641035, India

ravi@threatenedtaxa.org
} 


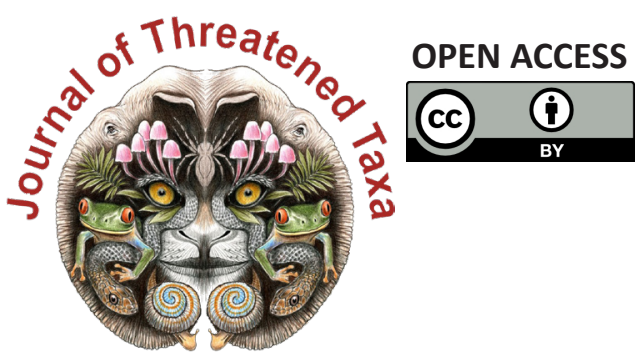

www.threatenedtaxa.org

The Journal of Threatened Taxa (JoTT) is dedicated to building evidence for conservation globally by publishing peer-reviewed articles online every month at a reasonably rapid rate at www.threatenedtaxa.org. All articles published in JoTT are registered under Creative Commons Attribution 4.0 International License unless otherwise mentioned. JoTT allows allows unrestricted use, reproduction, and distribution of articles in any medium by providing adequate credit to the author(s) and the source of publication.

\section{ISSN $0974-7907$ (Online) | ISSN $0974-7893$ (Print)}

\section{September 2021 | Vol. 13 | No. 11 | Pages: 19431-19674 Date of Publication: 26 September 2021 (Online \& Print) DOI: 10.11609/jott.2021.13.11.19431-19674}

Articles

Understanding human-flying fox interactions in the Agusan Marsh Wildlife Sanctuary as basis for conservation policy interventions

- Sherryl L. Paz \& Juan Carlos T. Gonzalez, Pp. 19431-19447

Argentinian odonates (dragonflies and damselflies): current and future distribution and discussion of their conservation

- A. Nava-Bolaños, D.E. Vrech, A.V. Peretti \& A. Córdoba-Aguilar, Pp. 19448-19465

\section{Communications}

The diel activity pattern of small carnivores of Western Ghats, India: a case study at Nelliampathies in Kerala, India

- Devika Sanghamithra \& P.O. Nameer, Pp. 19466-19474

Distribution and threats to Smooth-Coated Otters Lutrogale perspicillata (Mammalia: Carnivora: Mustelidae) in Shuklaphanta National Park, Nepal

- Gopi Krishna Joshi, Rajeev Joshi \& Bishow Poudel, Pp. 19475-19483

Wildlife hunting practices of the Santal and Oraon communities in Rajshahi, Bangladesh - Azizul Islam Barkat, Fahmida Tasnim Liza, Sumaiya Akter, Ashikur Rahman Shome \& M. Fazle Rabbe, Pp. 19484-19491

Ethnozoological use of primates in northeastern India

- Deborah Daolagupu, Nazimur Rahman Talukdar \& Parthankar Choudhury, Pp. 19492-19499

Factors influencing the flush response and flight initiation distance of three owl species in the Andaman Islands

- Shanmugavel Sureshmarimuthu, Santhanakrishnan Babu, Honnavalli Nagaraj Kumara \& Nagaraj Rajeshkumar, Pp. 19500-19508

Birds of Barandabhar Corridor Forest, Chitwan, Nepal

- Saneer Lamichhane, Babu Ram Lamichhane, Kapil Pokharel, Pramod Raj Regmi, Tulasi Prasad Dahal, Santosh Bhattarai, Chiranjibi Prasad Pokheral, Pabitra Gotame,

Trishna Rayamajhi, Ram Chandra Kandel \& Aashish Gurung, Pp. 19509-19526

On some additions to the amphibians of Gunung Inas Forest Reserve, Kedah,

Peninsular Malaysia

- Shahriza Shahrudin, Pp. 19527-19539

Reviews

A review of research on the distribution, ecology, behaviour, and conservation of the Slender Loris Loris lydekkerianus (Mammalia: Primates: Lorisidae) in India

- Mewa Singh, Mridula Singh, Honnavalli N. Kumara, Shanthala Kumar, Smitha D. Gnanaolivu \& Ramamoorthy Sasi, Pp. 19540-19552

Bivalves (Mollusca: Bivalvia) in Malaysian Borneo: status and threats

- Abdulla-Al-Asif, Hadi Hamli, Abu Hena Mustafa Kamal, Mohd Hanafi Idris, Geoffery James Gerusu, Johan Ismail \& Muyassar H. Abualreesh, Pp. 19553-19565

Disentangling earthworm taxonomic stumbling blocks using molecular markers

- Azhar Rashid Lone, Samrendra Singh Thakur, Nalini Tiwari, Olusola B. Sokefun \&

Shweta Yadav, Pp. 19566-19579

A reference of identification keys to plant-parasitic nematodes (Nematoda: Tylenchida) Tylenchomorpha)

- Reza Ghaderi, Manouchehr Hosseinvand \& Ali Eskandari, Pp. 19580-19602

Short Communications

Catalogue of herpetological specimens from Meghalaya, India at the Salim Ali Centre for Ornithology and Natural History

-S.R. Chandramouli, R.S. Naveen, S. Sureshmarimuthu, S. Babu, P.V. Karunakaran \&

Honnavalli N. Kumara, Pp. 19603-19610
A preliminary assessment of odonate diversity along the river Tirthan, Great Himalayan National Park Conservation Area, India with reference to the impact of climate change - Amar Paul Singh, Kritish De, Virendra Prasad Uniyal \& Sambandam Sathyakumar, Pp. 19611-19615

A checklist of orthopteran fauna (Insecta: Orthoptera) with some new records in the cold arid region of Ladakh, India

- M. Ali, M. Kamil Usmani, Hira Naz, Tajamul Hassan Baba \& Mohsin Ali, Pp. 19616-19625

New distribution records of two Begonias to the flora of Bhutan

- Phub Gyeltshen \& Sherab Jamtsho, Pp. 19626-19631

Rediscovery of Aponogeton lakhonensis A. Camus (Aponogetonaceae): a long-lost aquatic plant of India

- Debolina Dey, Shrirang Ramchandra Yadav \& Nilakshee Devi, Pp. 19632-19635

Glyphochloa acuminata (Hack.) Clayton var. laevis (Poaceae): a new variety from central Western Ghats of Karnataka, India

- H.U. Abhijit \& Y.L. Krishnamurthy, Pp. 19636-19639

A cytomorphological investigation of three species of the genus Sonchus L. (Asterales: Asteraceae) from Punjab, India

- M.C. Sidhu \& Rai Singh, Pp. 19640-19644

Dryopteris lunanensis (Dryopteridaceae) - an addition to the pteridophytic diversity of India

- Chhandam Chanda, Christopher Roy Fraser-Jenkins \& Vineet Kumar Rawat, Pp. 1964519648

Notes

First record of Spotted Linsang Prionodon pardicolor (Mammalia: Carnivora:

Prionodontidae) with photographic evidence in Meghalaya, India

- Papori Khatonier \& Adrian Wansaindor Lyngdoh, Pp. 19649-19651

First record of the Eastern Cat Snake Boiga gocool (Gray, 1835) (Squamata: Colubridae) from Tripura, India

- Sumit Nath, Biswajit Singh, Chiranjib Debnath \& Joydeb Majumder, Pp. 19652-19656

First record of the genus Tibetanja (Lepidoptera: Eupterotidae: Janinae) from India - Alka Vaidya \& H. Sankararaman, Pp. 19657-19659

Austroborus cordillerae (Mollusca: Gastropoda) from central Argentina: a rare, little-known land snail

- Sandra Gordillo, Pp. 19660-19662

Intestinal coccidiosis (Apicomplexa: Eimeriidae) in a Himalayan Griffon Vulture Gyps himalayensis

- Vimalraj Padayatchiar Govindan, Parag Madhukar Dhakate \& Ayush Uniyal, Pp. 1966319664

Two new additions to the orchid flora of Assam, India

- Sanswrang Basumatary, Sanjib Baruah \& Lal Ji Singh, Pp. 19665-19670

Wildlife art and illustration - combining black and white ink drawings with colour: some experiments in Auroville, India

- M. Eric Ramanujam \& Joss Brooks, Pp. 19671-19674
Publisher \& Host

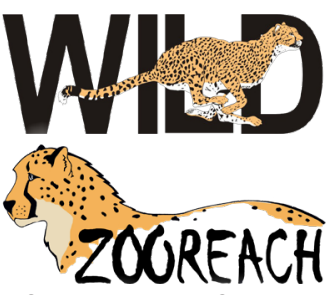

